\title{
MALINCHE: ENTRE O IMPERIALISMO ESPANHOL E UM NOVO PROJETO DE NAÇÃO IMAGINADA PARA O MÉXICO
}

\author{
MALINCHE: BETWEEN THE SPANISH IMPERIALISM AND A NEW \\ PROJECT TOWARDS AN IMAGINED NATION TO MEXICO
}

\section{Valdirene Rosa da Silva Melo ${ }^{1}$}

Resumo: Malinche, publicado em 2006 pela escritora mexicana Laura Esquivel, é uma versão romanceada que une fatos históricos à imaginação na narrativa que descreve a trajetória da índia asteca Malinalli, mais conhecida como Malinche, e o seu controvertido papel como intérprete e tradutora do colonizador espanhol Hernán Cortés no processo de colonização e conquista do México, que culminou com o massacre e extinção da civilização asteca pelo imperialismo espanhol. O objetivo deste trabalho será desenvolver, sob a ótica dos estudos pós-coloniais, uma leitura da obra que se proponha a detectar traços marcantes do imperialismo espanhol, que detentor de vetores de força e poder tenta impor através da barbárie, a cultura, a língua, a religião e os costumes ocidentais para as populações indígenas. Também será proposta uma leitura que leve a uma apreciação da índia Malinalli como um ser dividido entre várias culturas, levando-a a um processo de hibridização cultural que culminaria, dentro de seus questionamentos, a um novo projeto de nação imaginada para o seu povo, e que por força da violência da colonização impetrada pelo colonizador europeu, não pode ser compreendido e posto em prática.

Palavras-chave: colonizador, civilização asteca, hibridização cultural

Abstract: Malinche, published in 2006 by the Mexican writer Laura Esquivel is a romanticized version that combines historical facts with imagination in the narrative that describes the trajectory of the Aztec indian Malinalli, better known as Malinche, and her controversial role as an interpreter and translator of the Spanish colonizer Hernán Cortés in the process of colonization and conquest of Mexico, which culminated in the massacre and extinction of the Aztec civilization by the Spanish imperialism. The objective of this work is to develop, from the perspective of postcolonial studies, a reading of the narrative which aims to detect significant traces of the Spanish imperialism, that holder of vectors of force and power tries to impose through barbarism, the culture, language, religion and western customs towards Indigenous peoples. We also propose a reading that leads to an appreciation of the Indian Malinalli as divided among various cultures, leading her to a process of cultural hybridization that would culminate, within her questionings, to a new project of imagined nation for her people, and that under the violence of colonization imposed by European colonizers, cannot be understood and implemented.

Keywords: colonizer, Aztec civilization, cultural hybridization

\section{Introdução: Breves considerações sobre o romance histórico}

Malinche, da escritora mexicana Laura Esquivel, é uma obra literária que estabelece um diálogo sutil entre história e ficção. Baseada em fatos reais, trata-se de um romance histórico em que a autora combina episódios históricos e imaginação, levando-nos a uma reflexão sobre possibilidades não tecidas pela História oficialmente documentada. Considerado um gênero híbrido

\footnotetext{
${ }^{1}$ Mestre em Letras pela Universidade Federal do Piauí - Área de concentração: Estudos Literários. Professora de língua portuguesa e estrangeira da rede pública municipal e estadual do Piauí. E-mail: guaranimel@yahoo.com.br; http://lattes.cnpq.br/2793166589825698
} 
por se apropriar de fatos históricos para a ambientação da narrativa ficcional, o romance histórico exige do leitor um pacto quanto à sua interpretação, uma vez que a presença de referenciais históricos não pode ser ignorada em prol de uma leitura que leve em consideração apenas a imaginação criativa do autor. Segundo Rogério Miguel Puga (2006, p.03):

Tentar definir o romance histórico leva-nos obrigatoriamente para o campo da história e da ficção, uma vez que o subgênero supõe a existência de referentes extratextuais verificáveis que sustentam parte da rede de significações do texto ficcional.

O diálogo entre história e literatura é uma questão antiga e controversa. Para Sandra Jatahy Pesavento (2002) ambas são narrativas que representam a realidade, porém o tipo de relato proposto por cada uma é que estabelece a diferença entre ambas:

O historiador busca recriar o que teria se passado um dia, e o escritor de literatura cria um enredo que poderia também ter ocorrido. Nesse sentido, ambas as representações são plausíveis e tratam de convencer o leitor e transportá-lo a um outro tempo, mas só o historiador empenha-se em demonstrar que a sua versão não apenas 'poderia ter sido', mas 'efetivamente foi'. (PESAVENTO, 2002, p. 12)

O romance histórico surgiu universalmente no início do século XIX, na vigência do Romantismo, e tinha como característica a reconstituição dos costumes da época, misturando ao seu enredo fictício personagens ou fatos verídicos. A sua origem está diretamente relacionada à obra literária de Walter Scott. Embora Scott não possa ser considerado o fundador do romance histórico, foi a partir do lançamento de $W$ aterly que o romance histórico obteve notoriedade e popularidade: “apenas com Walter Scott (1771-1832), o romance vai ambicionar recriar épocas e mundos, tomando para si a tarefa de demonstrar, por meios artísticos, que as circunstâncias e personagens históricas existiram de certa maneira" (MENDES, 2008, p.2). Recriando a história através da recuperação de tradições populares, e apropriando-se dela ao mesclar os conflitos das personagens com os acontecimentos históricos, Scott traz inovações que os romances gótico, préromântico e de aventuras não dispunham ao colocar a História apenas como pano de fundo de suas ações. Neste caso, o romance histórico estreita a relação literatura e realidade: "Walter Scott conseguira criar uma interação entre a personagem e o momento histórico ao qual ela pertence, transformando a História, antes puro décor, em causadora de especificidades nos caracteres das personagens.” (MENDES, 2008, p. 3)

Contribuindo para a criação de possibilidades do que 'poderia ter sido', o romance histórico deixa entrever um olhar de significações que escapa à História, valendo-se principalmente das idéias, das palavras, dos pensamentos e sentimentos que os registros de História silenciaram, podendo a literatura ser esta fonte que:

[...] pode dar aquele 'algo mais' que os documentos comumente usados pela história não fornecem. Referimo-nos ao que se poderia chamar as sensibilidades ou a 'sintonia fina' de uma época, as características essências que estariam na raiz dos modos de pensar, sentir, agir e, sobretudo, de representar o mundo. (MENDES, 2008, p. 15)

Aproximando-se do real, o romance histórico ao reconstruir uma época ou fato histórico exige uma pesquisa aprofundada da época que vai ser narrada, dos costumes, dos ambientes, da fala, a fim de impor um caráter de verossimilhança que dará mais credibilidade à história ficcionalizada. Ressalte-se, porém, que o texto historiográfico valendo-se do registro dos fatos em seu caráter informativo e objetivo, pretende um sentido único para sua leitura e não alcança o nível de multiplicidade de sentidos do texto literário, dada a liberdade do romancista de criar e subjetivar os mesmos fatos históricos contados pelo historiador. Neste sentido são ainda mais distintos os papéis do historiador e do romancista histórico: 
O historiador age com rigor científico: parte dos fatos, dos documentos e registros que nos são apresentados através da leitura daquilo que já existia, ou seja, ele constrói sua narrativa histórica sob a forma de 'versão'. Embora possa estar cientificamente comprovada, ela é uma 'representação do real', ou seja, a reconfiguração histórica do passado é, em última instância, a interpretação daquilo que o historiador entende que tenha ocorrido. O romancista, ainda que utilize as mesmas fontes que o historiador, reproduz este passado com liberdade e imaginação, pelo emprego da subjetividade, tanto a sua quanto a dospersonagens que recria, não tendo que ocultar tal procedimento, pois o seu discurso acena para aquilo que, nestas circunstâncias e diante de evidências expostas nas fontes, poderia ter ocorrido. (FLECK, apud ZUFFO, p.13-14)

O romance histórico pode favorece o diálogo que o leitor vai empreender com a história, enriquecendo-o de detalhes que só o romancista pode lhe dar. Literatura e História, cada uma com suas particularidades específicas, narram o fato ocorrido de maneiras distintas. Embora ambas disputem a primazia de fornecer narrativas e interpretações para a tomada de consciência do leitor em relação à apropriação da realidade factual, isso não significa que estas duas formas de representação da realidade não possam se aliar no sentido de acrescentar ao leitor experiências distintasde elaboração da realidade, pois conforme nos afirma Sinder (2000, p. 256): "a narrativa da nação será realizada em conjunto pela escrita da história e da literatura. Onde fatos e fontes não puderem ser utilizados, caberá à ficção preencher as lacunas do nosso passado mediante a criação de tramas ficcionais".

\section{Malinche: entre muitos deuses}

O enredo de Malinche se dá em grande parte a partir da chegada de Hernán Cortés ao México em 1519. Ao chegar ao México, o conquistador foi confundido por muitos como o deus Quetzalcóatl, que segundo crenças indígenas, havia prometido que voltaria do exílio para acabar com os sacrifícios humanos, neste caso, cometidos em grande parte pelo imperador asteca Montezuma. Até o próprio Montezuma acreditou que Hernán Cortés era o Deus Quetzalcóatl devido às previsões de seus antepassados que indicavam para aquele ano o retorno de Quetzalcóatl, o qual viria, segundo as profecias, reclamar o trono de Montezuma e sua cidade Tenochtitlán, que contava na época com uma populaçaõ aproximada de 400 mil habitantes. Assim, Montezuma atribuiu à Hernán Cortés o aspecto de divindade. Contribuiu também para esta crença o fato do deus Quetzalcóatl ser associado ao sol e à cor amarela, e o aspecto físico de Cortés: louro, branco, era outra semelhança que os astecas assimilaram como sendo a reencarnação do deus Quetzalcóatl

O nome Quetzalcóatl significa “serpente de plumas”, e dentro das crenças astecas está relacionado ao mito da criação. O retorno do deus Quetzalcóatl preconizava a chegada de novos tempos, e estava previsto segundo as lendas astecas para o ano de 1519, coincidentemente o ano em que Cortés chegou ao México. A cultura asteca está intimamente ligada às suas crenças religiosas, que exerciam total domínio sobre a vida deste povo indígena e cujos deuses comandavam os acontecimentos mais coditianos do povo e regiam os diversos fenômenos da natureza, desde um simples nascer do sol à chuva, o vento e à produtividade da terra, exemplos que ilustram bem o fascínio que os deuses exerciam sobre os astecas.

Os astecas eram politeístas e se destacaram pela prática de oferecer sacrifícios humanos em larga escala para agradar aos seus deuses, sendo alguns deles: Quetzalcóatl - deus exilado que voltaria para comandar os astecas e considerado um líder entre as divindades, Tlaloc - deus da tempestade, dos raios, da água e do trovão, Tonatiuh - o Sol, Mixcoatl - deus da caça, Metztli - a Lua, além de vários outros.Eram comuns festivais onde se ofereciam aos deuses sacrifícios, oferendas e cerimônias, a fim de que eles pudessem retribuir, sendo o sacrifício humano a principal crença da religião asteca.

É neste contexto histórico de sacrifícios humanos a vários deuses que se desenvolve a trama de Malinche, uma jovem índia asteca, de nome Malinalli. No enredo de Malinche consta 
que, na idade de três anos aproximadamente, com a morte do pai da protagonista, a mãe volta a casar com um cacique da tribo dos astecas, e a pequena índia passa a viver com a avó paterna, com quem aprende grande parte dos costumes de sua tribo e o idioma asteca Nahuatl, sua língua nativa.

Porém, dois fatos mudam o rumo dos acontecimentos: a avó paterna falece e a mãe engravida novamente do novo marido. Segundo os costumes, para que o bebê tivesse direito à herança, a mãe teria que dar Malinalli. Esta, então, com a idade aproximadamente de seis anos de idade, é presenteada, ou possivelmente vendida, aos índios maias da tribo Xicalango, e tratada como escrava.

Quando da chegada dos espanhóis ao México, ela, já então uma adolescente de aproximadamente treze anos, foi juntamente com mais dezenove índias, outra vez oferecida como presente, desta vez ao espanhol Hernán Cortés, chefe da expedição colonizadora espanhola.

Cortés já tinha um tradutor do idioma maia: o padre espanhol Jerônimo de Aguillar, mas não possuía um intérprete para o idioma dos astecas. Muito inteligente, a índia Malinalli havia aprendido o idioma espanhol, e, pela sua origem asteca, dominava bem o idioma asteca nahuatl, além de ser fluente no idioma dos maias. Estas habilidades linguísticas não passaram despercebidas por Cortés, que passou a usá-la como sua intérprete e negociadora com os índios astecas, estes liderados pelo imperador Montezuma.

O termo "malinche" veio após o batismo de Malinalli, que foi renomeada após a cerimônia cristã com o nome de Marina, nome da mãe de Cortés. Com a dificuldade dos índios de pronunciar o " $r$ " espanhol, a índia passou a ser chamada de Malintzin, e os espanhóis, por sua vez, com dificuldade de falar como os índios, passaram a chamá-la de Malinche.

Quando Malinalli conhece Cortés, ela pensa que se trata do próprio Deus Quetzalcóatl que regressa para libertar o seu povo. Segundo a lenda asteca, Quetzalcóatl, o mais importante deus da mitologia mexicana, havia atravessado o mar afirmando que um dia voltaria. Tanto Malinalli quanto Montezuma interpretaram a chegada de Hernán Cortés como o regresso do deus Quetzalcóatl e o fim de um ciclo de profecias que relatavam a volta deste deus para retomar o seu reino. Aproveitando-se destas crenças Hernán Cortés deu inicio à conquista do território mexicano, que culminou com o extermínio da civilização asteca.

Malinche, a partir do imaginário coletivo que se formou em torno de sua figura e atuação na conquista do México, foi considerada pelo povo mexicano como traidora de sua pátria, mas ao ler a obra de Laura Esquivel pode-se repensar este controverso papel da índia, e sob o olhar literário refletir sobre as construções simbólicas negativas que se formaram em torno de sua imagem. Este confronto de ideias em torno de sua figura emblemática traz à tona novas construções para o imaginário coletivo de uma nação que condenou uma índia escrava que foi, assim como seu povo, submetida e envolvida em tramas complexas, que não se explicam de forma simplória e requerem maior profundidade nas análises, que devem levar em conta uma pluralidade de contextos. Neste sentido, o discurso literário atua de forma a repensar as memórias que já existem e apresentar possibilidades de novas leituras e questionamentos para os registros do passado, passando o texto literário a ser uma fonte para apropriação e elaboração de novos significados, ainda que mediados pela sensibilidade artística do escritor.

\section{Malinche: narrativa de uma barbárie no processo de colonização mexi- cana}

A obra Malinche faz um resgate do passado mexicano pré-colombiano e de uma memória que não é individual, mas coletiva, e que deseja ser lembrada e revivida para se chegar à compreensão do presente histórico e do atual conceito de nação mexicana, que ainda é assombrado por fantasmas do passado, do massacre de uma civilização inteira. Vozes e memórias que foram silenciadas após a chegada de Hernán Cortés e que por meio da escrita literária pode ser um dos

https://periodicos.unifap.br/index.php/letras

Macapá, v. 9, n. 2, $2^{\circ}$ sem., 2019 
meios dessas memórias serem novamente recuperadas, conhecidas ou simplesmente questionadas.

Cada vez mais, na construção da identidade das nações e de uma memória coletiva local, uma grande quantidade de narrativas busca resgatar a história dos seus antepassados, com o objetivo de reescrever um novo diálogo com as origens mais profundas da nação, de um povo, com todos seus antagonismos e ambivalências, trazendo um novo olhar para o que antes havia sido esquecido, omitido ou não revelado. Segundo a crítica póscolonialista, a escrita destas memórias vem corresponder a um ensejo de desnudar e desvelar passados não revelados, de compreender o presente e alcançar uma autoconsciência que só seria possível através da 'exumação' dos seus mortos:

[...] nas Américas e em outras partes do mundo, uma quantidade sempre maior de nacionalistas "de segunda geração" aprendeu a falar "pelos" mortos, com os quais seria impossível ou indesejável estabelecer uma ligação linguística. Este ventriloquismo às avessas ajudou a abrir caminho para um indigenismo autoconsciente, sobretudo na América Latina. No limite: mexicanos falando em espanhol "em nome" das civilizações pré-colombianas, cujas línguas eles não entendem. (ANDERSON, 2008, p. 271, grifos do autor).

Os estudos pós-coloniais trata-se de uma crítica recente que ganhou grande amplitude e institucionalização como estudo acadêmico nos anos 1980-1990, tendo sido publicados muitos livros para discussão de idéias a respeito do universo imperialista, do "[...] maniqueísmo por ele adotado, a manipulação constante do poder e a aplicação do fator desacreditador na cultura do outro" (BONNICI, 2000, p. 8). A partir da recuperação da história reprimida, novos discursos em relação à história de cada nação vão se formando no imaginário coletivo.

Assim sendo, a obra Malinche, de Laura Esquivel, publicado no México em 2006, é uma importante contribuição para que novas reflexões sejam feitas e abordadas sob diferentes olhares e perspectivas de leitura, visando ampliar o universo de significações e representações acerca do processo de colonização espanhola no México, da reconstrução das possíveis relações entre colonizador/colonizado e dos mecanismos de força usados pelo imperialismo espanhol para dominar e impor um modelo de pensamento hegemônico ocidental.

Em territórios marcados por um processo de colonização brutal como foi o México, que culminou com o desaparecimento da civilização asteca, o universo ficcionado representado em Malinche abre espaço para uma discussão mais aprofundada sobre as consequências do imperialismo espanhol, e ilustra através de sua protagonista, a índia Malinalli, um constante questionamento das ações de poder e dominação impetrados pelos colonizadores. O processo de colonização e de exploração da terra, dos bens e das riquezas coloniais atuou como um propulsor do capitalismo mundial, processo este que quando aguçado na avidez pela conquista territorial utilizou de formas violentas de dominação das terras e dos colonizados. Alfredo Bosi alerta que atos violentos na conquista e expansão territorial foram uma constante na história: "o genocídio dos astecas e dos incas, obra de Cortez e de Pizarro, foi apenas o marco inaugural. Os recomeços foram numerosos" (BOSI, 1992, p.21).

No âmbito religioso, uma visão deformada da inferioridade da religião dos povos précolombianos que habitavam o México legitimaram por parte da religião católica um aparelho de dominação ideológica, que atuava no sentido de reprimir e proibir as crenças religiosas politeístas professadas por estes povos, substituindo-as por padrões cristãos, e justificando que em nome de Deus o colonizador escravizasse, matasse e praticasse grandes barbáries para punir aqueles que se fizessem rebeldes ou contrários ao que lhes estava sendo ensinado. Há uma passagem na obra Malinche que ilustra bem o que foi exposto:

O frenesi de assassinatos, saque e sangue durou dois dias, até que Cortés restabeleceu a ordem. Morreram ao todo cerca de 6 mil cholultecas. Cortés ordenou aos poucos sacerdotes sobreviventes que limpassem os templos dos ídolos, lavassem as paredes e o chão e, em seu lugar, colocaram cruzes e 
efígies da Virgem Maria.

Segundo Cortés, esse horror foi bom para mostrar aos nativos que todos os seus ídolos eram falsos, mentirosos, não os protegiam adequadamente, porque, mais do que deuses eram demônios. A conquista para Cortés, era uma luta do bem contra o mal. Do Deus verdadeiro contra os deuses falsos. De seres superiores contra inferiores. Considerava uma missão sagrada salvar todos esses nativos da ignorância, que provocava segundo ele, todo tipo de atos selvagens e incivilizados. (ESQUIVEL, 2007, p. 100)

A violência dos colonizadores foi muitas vezes mascarada por um caráter civilizatório diante de uma suposta supremacia da cultura europeia, justificando sua barbárie e tentando imprimir nos povos conquistados um caráter de subalternidade. Em nome da propagação da fé cristã foram permitidas Cruzadas e guerras com o objetivo de colonizar e escravizar povos, e impor a submissão e catequização dos conquistados, atos justificados como uma luta contra povos infiéis, supostamente inferiores, e cuja conquista seria uma vitória em nome de Deus:

Uma das armas da barbárie cristã foi a utilização de Satanás. Obviamente, é preciso ver nessa figura o separador, o rebelde, o negador, o inimigo mortal de Deus e dos humanos. Aquele que se opuser e que não quiser renunciar à sua diferença fatalmente estará possuído por Satanás. Essa máquina argumentativa delirante foi uma das formas encontradas pelo cristianismo para exercer sua barbárie." (MORIN, 2009, p. 21)

Levar a fé cristã para os povosconsiderados "bárbaros" era um dos objetivos do projeto colonial, que aliado à busca por metais preciosos, em especial ouro e prata, serviriam como justificativa para que Cortés e demais colonizadores espanhóis ou de outras nacionalidades cometessem grandes atrocidades, especialmente por se julgarem como os únicos portadores da fé e considerarem os nativos como "selvagens". Frei Bartolomé de las Casas (1417-1566), que fez uma campanha em defesa dos índios do novo continente, relatou em seus manuscritos muitas atrocidades cometidas em contatos violentos dos colonizadores com os colonizados, como a passagem transcrita a seguir:

Os espanhóis, com seus cavalos, suas espadas e lanças começaram a praticar crueldades estranhas; entravam nas vilas, burgos e aldeias, não poupando nem as crianças e os homens velhos, nem as mulheres grávidas e parturientes e lhes abriam o ventre e as faziam em pedaços como se estivessem golpeando cordeiros fechados em seu redil. Faziam apostas sobre quem, de um só golpe de espada, fenderia e abriria um homem pela metade, ou quem, mais habilmente e mais destramente, de um só golpe lhe cortaria a cabeça, ou ainda sobre quem abriria as entranhas de um homem de um só golpe. Arrancavam os filhos dos seios da mãe e lhes esfregavam a cabeça contra os rochedos [...] Faziam certas forcas longas e baixas, de modo que os pés tocavam quase a terra, um para cada treze, em honra e reverência de Nosso Senhor e de seus doze Apóstolos (como diziam) e deitando-lhes fogo, queimavam vivos todos os que ali estavam presos. Outros, a quem quiseram deixar vivos, cortaramlhes as duas mãos e assim os deixavam. (LAS CASAS, 2007, p.31)

É importante ressaltar que a ambição e o desejo de enriquecimento rápido e sem escrúpulos por parte dos conquistadores levaram não só a um sistema de dominação que se utilizava de formas violentas e massacrantes contra os povos dominados, como também formas de dominação psicológica, como aconteceu com Cortés que ao ser confundido com o deus Quetzalcóatl se utilizou desta poderosa estratégia para ganhar a confiança do imperador asteca Montezuma que acreditava nas previsões cíclicas dos seus antepassados sobre o retorno do citado deus asteca. Posteriormente, Cortés se utilizou da discórdia que existia entre diversas comunidades indígenas que estavam sob o jugo de Montezuma e procurou fazer alianças com os nativos para conseguir mais facilmente seus intentos de conquistar e derrubar o império asteca. Usando estratégias psicológicas hábeis, Cortés passou a ser visto pelos grupos indígenas contrários a Montezuma como o grande libertador. Laura Esquivel, com seu poder de criação literária,ilustra na passagem a seguir a entrega voluntária do reino do imperador para Cortés, pois Montezuma acreditava na di- 
vindade do colonizador:

O senhor saiu das nuvens e das trevas, do lugar escondido a todos. É isso, certamente, o que nos disseram os reis passados, que o senhor voltaria a reinar nestes reinos, voltaria a sentar em seu trono e em sua cadeira. Agora vejo que é certo o que nos disseram.

Seja bem-vindo. Teve muito trabalho para atravessar tão longo caminho. Agora descanse! Aqui estão sua casa e palácios; tome-os e neles descanse com todos os seus capitães e companheiros que vieram consigo. (ESQUIVEL, 2007, p. 126)

Malinalli também ansiava e acreditava no retorno do deus Quetzalcóatl, julgando os colonizadores como corpos que reencarnavam os seus deuses:

Malinalli reclamava o retorno do senhor Quetzalcoatl - principal opositor dos sacrifícios humanos -, e estava até disposta a acreditar que seu deus protetor elegera o corpo dos recém-chegados a essas terras para dar forma ao seu espírito, para que eles o acolhessem em seu interior. (ESQUIVEL, 2007 p. 23)

O que encontramos em diversos processos de colonização na América Latina são projetos de expansão marítima e comercial que se beneficiaram da conquista da terra e dos bens materiais para gerar grandes lucros à Europa, favorecidos por relações de poder e barbárie apoiadas por um imperialismo religioso cristão que imbuía nos colonizadores uma suposição de catequizar povos "infiéis" em nome de Deus. Aliada a estes dois vetores de força e coerção, no caso do México temos ainda a estratégia psicológica utilizada por Cortés de beneficiar-se de crenças e lendas dos povos ameríndios para fortalecer o seu poder de conquista e ganhar aliados a fim de conseguir seus intentos de riqueza e poder, mesmo que para isso tivesse que extinguir uma civilização indígena, que foi silenciada em sua cultura, língua, tradições e crenças.

O romance histórico Malinche traz um rico e minucioso retrato do poder imperialista espanhol na conquista do México e aborda questões importantes, tais como:

a) O massacre e extinção da civilização asteca pelos espanhóis:

Durante mais de duas horas os espanhóis apunhalaram, golpearam e mataram todos os nativos reunidos ali. Malinalli correu para se refugiar num canto, e com os olhos espantados, viu Cortés e seus soldados cortarem braços, orelhas, cabeças. O som do metal rasgando músculos e ossos, os gritos, os lamentos aterrorizaram seu coração. (ESQUIVEL, 2007, p. 99)

$[\ldots]$

Os morteiros e os arcabuzes despedaçavam a multidão aterrorizada. Ninguém pôde fugir. Ninguém conseguiu escalar os muros. Todos foram assassinados sem chance de defesa.

Enquanto assassinavam todos os homens ali reunidos, abriram-se as portas do pátio e Malinalli fugiu horrorizada. $\mathrm{Na}$ cidade, os 5 mil tlaxcaltecas e os mais de quatrocentos cempoalenses aliados de Cortés saqueavam tudo. Malinalli evitou-os e correu apavorada até chegar ao rio. Era impressionante o ódio com que assassinavam homens, mulheres e crianças. O templo de Huitzilopochtli, o deus que ressaltava o domínio mexicano, foi incendiado. (ESQUIVEL, 2007, p. 100)

$[\ldots]$

Cortez determinou a destruição das casas e assim começou a destruição da cidade. (ESQUIVEL, 2007, p. 146)

b) A imposição de uma religião monoteísta em contraposição às crenças politeístas dos nativos:

Tal reflexão o levou a concluir que talvez essa fosse sua verdadeira missão, salvar das trevas todos os nativos, pô-los em contato com a religião verdadeira, acabar com a idolatria e a nefasta prática dos sacrifícios humanos [...] (ESQUIVEL, 2007, p. 54).

c) O batismo cristão dos índios e mudança de nomes indígenas para nomes próprios da cultura do colonizador: 
Quando a cerimônia terminou, Malinalli se aproximou de Aquilar, o frade, para perguntar-lhe qual era o significado de Marina, o nome que haviam acabado de lhe dar. O frade respondeu que Marina era a que vinha do mar. (ESQUIVEL, 2007, p. 48)

$[\cdots]$

Cortés, depois de batizá-lo com o nome de Fernando, mandou-o enforcar numa painera, a árvore sagrada dos maias, num lugar de Tabasco. (ESQUIVEL, 2007, p. 147)

d) Apropriação das índias como objeto de satisfação sexual pelo colonizador:

A mente ambiciosa de Cortés não agüentou mais e quis possuir Malinalli e seu deus ao mesmo tempo. Em sua mente explodiu o prazer, e o fogo de seu coração quis evaporar para sempre esse deus chamado Tlaloc, esse deus-água. Carregou Malinalli, tirou-a da água e ali, na orla do rio, penetrou-a com força. (ESQUIVEL, 2007, p. 84)

$$
[\ldots]
$$

Era uma construção palaciana que maravilhou Cortés; quando se instalou em seu quarto, mandou chamar Malinalli e fornicou desenfreadamente com ela, como maneira de celebrar seu triunfo e ao mesmo tempo negá-lo. (ESQUIVEL, 2007, p. 128)

e) A substituição dos deuses venerados nos templos astecas por símbolos cristãos:

Cortés ordenou aos poucos sacerdotes sobreviventes que limpassem os templos dos ídolos, lavassem as paredes e o chão e, em seu lugar colocaram cruzes e efígies da Virgem Maria. (ESQUIVEL, 2007, p. 100)

$$
[\ldots]
$$

Quando Cortés proibiu os sacrifícios humanos e, num ato de violência, subiu ao templo de Huitzilopochti, enfrentou os sacerdotes, venceu-os e logo, com uma barra de ferro, golpeou a máscara de ouro que cobria a cabeça do ídolo e o destroçou, colocando em seu lugar uma imagem da Virgem Maria, o mercado mostrou todas as faces da indignação. (ESQUIVEL, 2007, p.133)

f) A ambição pelo ouro e prata e a destruição dos objetos de arte dos astecas:

Cortés se dedicou a roubar - e não havia outra palavra para descrever aquilo - tudo o que pôde.

Os excelentes trabalhos em ouro e pedras preciosas foram em sua maioria desbaratados; os mais belos tesouros de artes decorativas foram destroçados para arrancar o ouro que continham." (ESQUIVEL, 2007, p. 129)

Cortés e seus homens não só dispuseram das jóias dos antigos governantes como também das do próprio Montezuma. O tesouro pessoal, acumulado em seus anos de reinado, incluindo os mais belos trabalhos de arte plumária e de ouro - em forma de penachos, peitorais, braceletes, anéis para o nariz, tornozeleiras, escudos redondos, coroas, faixas para as bonecas e guizos de ouro para os tornozelos foi objeto de rapina.

No pátio do palácio de Axatacatl, os espanhóis se dedicaram a arrancar o ouro dos finos trabalhos de pena e os fundiam em lingotes. Ao fim do dia, o pátio do palácio parecia um galinheiro onde depenaram aves preciosas." (ESQUIVEL, 2007, p. 132)

\section{O hibridismo da índia Malinche}

Para Néstor Garcia Canclini o hibridismo trata-se de "processos socioculturais nos quais estruturas ou práticas discretas, que existiam de forma separada, se combinam para gerar novas estruturas, objetos e práticas" (CANCLINI, 1997, p.19). Assim, um elemento cultural existente em uma determinada cultura ao entrar em contato e confronto com outra, se combinaria para revelar uma terceira composição cultural que mesclaria um pouco de cada cultura. Esta seria uma concepção mais voltada para a integração e interação entre elementos culturais diversos. Em $M a$ linche, a hibridização da protagonista começa ainda criança quando esta, por forças maiores, deixa a cultura asteca e vai para a cultura maia, tendo que aprender e adaptar-se a uma nova língua, e agregar novos elementos culturais porventura não existentes em sua cultura anterior. Por serem 
os grupos indígenas Maia e Asteca mais próximos culturalmente, existindo em ambos, por exemplo, a crença em vários deuses, propomos nesta abordagem de Malinche nos determos na análise a um terceiro contato que seria entre a cultura indígena e a europeia.

No conceito de hibridismo formulado por Homi Bhabha (2003), este deixa entrever uma ameaça à autoridade cultural e colonial, de modo que o processo resultante do confronto entre as duas culturas: do dominador e do dominado, revela nesta relação de forças a subversão do conceito de identidade pura da autoridade dominante através da ambivalência criada pela negação, variação, repetição e deslocamento, podendo ser esta uma forma de resistir, de transgredir o projeto do dominador e exigir o reconhecimento da diferença:

O hibridismo é uma problemática de representação e de individuação colonial que reverte os efeitos da recusa colonialista, de modo que outros saberes "negados" se infiltrem no discurso dominante e tornem estranha a base de sua autoridade - suas regras de conhecimento. (BHABHA, 2003, p. 165, grifo do autor)

O hibridismo de que trata Bhabha dos povos colonizados e dominados é sugerido para esta análise quando a protagonista passa a ter contato com a cultura do colonizador europeu, pois há grandes mudanças de percepção de mundo e choques culturais mais fortes. Como podemos ver em algumas passagens ilustrativas da narrativa literária produzida por Laura Esquivel, a índia Malinalli parece estar dividida entre duas culturas: a sua (aqui considerada a das comunidades indígenas que habitavam o México) com todas as suas crenças politeístas e costumes, mas rejeitando firmemente os sacrifícios humanos, e a cultura do outro, do colonizador que pregava um deus único, bom e pacificador, que não aceitava sacrifícios humanos. Porém, um fato interessante se instala nesta ambivalência: o "deus" único e benevolente apregoado pelos colonizadores era reconstruído no imaginário da protagonista como o deus asteca (Quetzalcóatl), ocorrendo aí o elemento de hibridização cultural com um componente de negação, pois o deus Quetzalcóatl era o deus que a índia asteca aspirava e não ao deus cristão proposto pelos colonizadores.

Encantara-se ao escutar no sermão prévio ao batismo que o próprio Aquilar traduzira para todos eles que os espanhóis pediam que não continuassem a se deixar enganar por deuses falsos que exigiam sacrifícios humanos. Que o deus verdadeiro que eles traziam era bom e amoroso e nunca exigiria algo desse tipo. Aos olhos de Malinalli, esse deus misericordioso só podia ser o senhor Quetzalcoatl, que com roupas novas, regressava a essas terras para restaurar seu reino de harmonia com o cosmo. Urgia dar-lhe as boas-vindas, falar com ele. (ESQUIVEL, 2007, p. 51)

Porém, estar dividida entre duas culturas causava na protagonista um conflito interior, pois não conseguia se desfazer de suas antigas crenças, de sua cultura. Ao mesmo tempo, o contato com o colonizador lhe inspirava um novo conceito de nação imaginada, onde não havia espaço para rituais de sacrifícios humanos, tão comuns no cotidiano do seu povo. Incorporando e fazendo a fusão de aspectos da cultura indígena com elementos e conceitos da cultura do outro (do colonizador), a tornavam um ser híbrido e dividido entre dois mundos: "Para Malinalli, era urgente e necessário se reencontrar, reencontrando seus deuses" (ESQUIVEL, 2007, p. 186). Dessa forma, Malinalli se vê diante da necessidade de negociar com a cultura do colonizador sem se deixar ser assimilada totalmente por ela: ou seja, o hibridismo de Malinche incorpora elementos novos da cultura do outro (colonizador), mas sem perder traços de sua cultura, remetendo ao elemento transgressor proposto por Bhabha: "A mudança que ela queria para sua gente era simplesmente o fim dos sacrifícios humanos, mas esperava que o restante continuasse igual. Sobretudo o culto a Quetzalcoatl.” (Esquivel, 2007, p. 106)

Esta transgressão contempla não só o espaço da cultura do outro, como também se revela contestadora da própria cultura do ser híbrido, como pode-se perceber na passagem seguinte: 
Malinalli discordava totalmente da maneira como eles governavam, opunha-se a um sistema que determinava o que uma mulher valia, o que os deuses queriam e a quantidade de sangue que reclamavam para subsistir. Estava convencida de que urgia uma mudança social, política e espiritual. (ESQUIVEL, 2007, p. 22)

Neste processo de hibridização, esta transgressão da protagonista dos saberes "negados" desfaz o discurso de autoridade e de supremacia da cultura do outro (colonizador):

De nada servira a queda do império, o sacrifício perdurava e seria a herança deixada aos sobreviventes. Esse Cristo na cruz era dor sem fim. Era morte sem fim. Era morte eterna. Malinalli não acreditava que o sacrifício criasse a luz, e também que a luz se encontrasse em meio ao sacrifício. (ESQUIVEL, 2007, p. 181)

E passa então a ser um momento de [...] "re-articulação, ou tradução, de elementos que não são nem o Um, nem o Outro mas algo mais que contesta os termos e territórios de ambos" (BHABHA, 2003, p. 55). Vejamos esta reflexão no romance histórico de Esquivel:

A procura dos deuses é a procura de si próprio. E onde estamos escondidos? Na água, no ar, no fogo, na terra. Estamos na água, no rio escondido. A água faz parte de nosso corpo, mas não a vemos. Circula em nossas veias, mas não a sentimos. Só vemos a água externa. Só nos reconhecemos nos reflexos. Quando nos olhamos na água, também sabemos que somos luz, de outra forma não poderíamos nos refletir. Somos fogo, somos Sol. Estamos no ar, na palavra. Quando pronunciamos o nome de nossos deuses, pronunciamos nosso próprio nome. Eles nos criaram com sua palavra e nós o recriamos com a nossa. Deuses e homens são a mesma coisa. O filho do Sol, o filho da água, o filho do ar, o filho do milho nascem do ventre da Mãe Terra. Quando alguém encontra o Sol, o fogo em movimento, a água, o rio escondido, o ar, o canto sagrado, a terra, a carne do milho, dentro de si mesmo, converte-se em deus. (ESQUIVEL, 2007, p. 185)

Esta reflexão pressupõe um novo olhar para dentro de si mesmo, onde a procura dos deuses é o encontro com a identidade do ser colonizado. O ser híbrido da protagonista produz uma nova significação para a sua espiritualidade: o próprio indivíduo já seria capaz de converterse em deus. Para esta análise, sugerimos que no processo de hibridização cultural da protagonista as representações e discursos existentes, tanto de um lado como do outro são desconstruídas, reorganizadas, rearticuladas, para serem construídas outra vez, numa dinâmica que inclui a contestação de ambos poderes estabelecidos a fim de se opor a uma verdade "única", surgindo um espaço articulador, um "entre-lugar" proposto por Bhabha, onde o ser híbrido está dividido no interior dele próprio, gerando novos espaços de significação em que o sujeito é produtor e produto de uma cultura própria, situado no limite de duas culturas apropriadas.

\section{Considerações finais}

A história repensada através da literatura, assim é o romance Malinche, de Laura Esquivel, cuja proposta é abrir caminhos para novas reflexões, novos pensares e novas leituras da história. De uma história esquecida, não contada, omitida, ou simplesmente imaginada de uma maneira distinta a que se fez ao longo dos séculos e que nos leva a pensar que a história não pode ser tomada como uma verdade única, pronta e acabada. Deve ser sempre objeto de novas reflexões e a literatura desempenha um importante papel neste repensar, quando ficcionaliza a história e amplia as possibilidades de apropriação do conhecimento institucionalizado oficialmente. O espaço da narrativa é mexicano, mas poderia ser qualquer outro país colonizado, pois seguramente os efeitos brutais da colonização não teriam deixado de ser menos aterrorizantes e bárbaros. O olhar do escritor sobre a história é um olhar que vai além dos documentos históricos, entra no interior das personagens, revive o ambiente, o tempo, as tradições e costumes de uma época que passou, 
que não se pode mais voltar, mas se pode imaginar, e pensar em possibilidades do que "poderia" ter sido.

A violência da colonização como já foi comentada, muitas vezes foi mascarada por um caráter civilizatório, de resgatar povos "infiéis", "bárbaros", "selvagens" (do ponto de vista do imaginário do colonizador europeu) da heresia, da idolatria de deuses fal-

sos. A presunção de superioridade assumida pelo povo europeu, apoiada pelo poder ideológico da religião católica de "cristianizar" estes povos, sustentou processos de colonização e dominação brutais que tinha por finalidade primordial o enriquecimento da Coroa e daqueles que estavam a serviço dela, tentando submeter à escravidão todos aqueles que eram considerados como o outro (o não europeu, o "não civilizado", o não branco, o índio, o asiático) ou quando não muito menos destruindo e exterminando, por doenças ou por violência, aqueles povos que para o colonizador não possuíam almas e por isso mesmo não poderiam ser considerados seres humanos.

Abrir espaços para a compreensão do processo de colonização do México através da literatura é abrir as portas para novas significações e representações no presente, que ajudam a construir um novo imaginário de nação e atua como elemento conscientizador do processo de colonização como um complexo fator que se estabeleceu ao longo dos séculos e que continua exercendo seus reflexos na dinâmica atual, e que só a exumação dos fantasmas do passado é que poderá abrir novas perspectivas de transformação do imaginário coletivo que se firmou sob a postura hegemônica do colonizador e que muitas vezes apresenta apenas um lado da história, silenciando outras versões, outras verdades, outras possibilidades.

Quanto ao hibridismo que foi se manifestando na protagonista, sob a ótica do conceito de Bhabha utilizado para esta análise, detectamos um espaço de negociação e de subversão dos conceitos passados pelo colonizador, em momentos de negação ou recusa que culminam em um processo mais complexo de ambivalência do ser híbrido que, transitando entre duas ou mais culturas, tentará reconstruir, reorganizar, rearticular os saberes adquiridos e em conflito no confronto das culturas diversas. Neste espaço de confronto em que elementos culturais tentarão se impor a outros poderá resultar em uma terceira composição, que não será simplesmente a junção pacífica de duas culturas acolhidas pelo ser híbrido, mas uma configuração complexa de dualidades que acionará uma dinâmica constante de reavaliações e questionamentos, onde o ser híbrido seguirá deslocando, reorganizando os conhecimentos adquiridos, que o situará em um "entrelugar", um terceiro espaço de significações e de refiguramento da realidade.

Malinche, de Laura Esquivel, nos apresenta um convite para nos aproximarmos da história mexicana e repensá-la sob o olhar literário da autora que nos remete a uma nova pluralidade de significações, e nos oferece a possibilidade de releitura da história, da conquista mexicana pelo colonizador Hernán Cortés, da índia Malinalli, conhecida como Malinche, do imperialismo espanhol, e de muitos outros aspectos que poderão ser lidos e repensados, em possibilidades de reflexão sobre a obra literária que não se esgotam e que este trabalho visa apenas sugerir uma possibilidade de análise que venha a ser fonte inspiradora para novas proposições de estudo sobre o tema.

\section{Referências}

ANDERSON, Benedict. Comunidades Imaginadas: Reflexões sobre a origem e a difusão do nacionalismo. São Paulo: Companhia das Letras, 2008.

BHABHA, Homi. 2003. O local da cultura. Trad. de Myriam Ávila, Eliana Lourenço de Lima Reis e Gláucia Renate Gonçalves. Belo Horizonte: Editora da UFMG.

BONNICI, Thomas. O pós-colonialismo e a literatura: estratégias de leitura. Maringá: Eduem, 2000.

BOSI, Alfredo.Dialética da Colonização. 2ªed. São Paulo: Companhia das Letras. 1992.

https://periodicos.unifap.br/index.php/letras

Macapá, v. 9, n. 2, $2^{\circ}$ sem., 2019 
CANCLINI, Néstor García. Culturas Híbridas: estratégias para entrar e sair da modernidade. São Paulo: Edusp, 1997.

ESQUIVEL, Laura. Malinche. Trad. Léo Schlafman. Rio de Janeiro: Ediouro, 2007.

LAS CASAS, Frei Bartolomé de. O paraíso destruído: A sangrenta História da conquista da América espanhola. $2^{\mathrm{a}}$ ed. Porto Alegre: L\&PM, 2007.

MORIN, Edgar. Cultura e Barbárie Européias. Trad. Daniela Cerdeira. Rio de Janeiro: Bertrand Brasil, 2009.

PESAVENTO, Sandra Jatahy. O imaginário da cidade: visões literárias do urbano - Paris, Rio de Janeiro, Porto Alegre. $2^{\text {a }}$ Ed. Porto Alegre: Ed. Universidade/ UFRGS, 2002.

PUGA, Rogério Miguel. O essencial sobre o romance histórico. Lisboa: Imprensa Nacional - Casa da Moeda, 2006.

\section{Referências Eletrônicas:}

MENDES, Maria Lúcia Dias. A presença de Walter Scott e Jules Michelet no romance bistórico de Alexandre Dumas. IN: XI Congresso Internacional da ABRALIC: Tessituras, Interações e Convergências. São Paulo: USP: 2008. Disponível on line em: www.abralic.org/anais/cong2008/AnaisOnline/ .../MARIA_MENDES.pdf. Acessado em 26 de agosto de 2018.

SINDER, Valter. A reinvenção do passado e a articulação de sentidos: o novo romancebistórico brasileiro. In: Estudos Históricos. Rio de Janeiro, 2000, vol. 14, no 26. p. 253- 264. Disponível em: virtualbib.fgv.br/ojs/index.php/reh/article/.../2120. Acessado em 27 de agosto de 2018.

ZUFFO, Nilva. O romance histórico: a leitura da história pela ótica da ficção. Disponível on line em: www.diaadiaeducacao.pr.gov.br/portals/pde/arquivos/821-4.pdf. Acesso em 27 de agosto de 2018.

Envio: 30/08/2019

Aceite: 08/11/2019 